\title{
Prejudice and Social Distance of Diponegoro University Students in Establishing Inter-Personal Relationship with Members from Different Ethnic Groups
}

\author{
Turnomo Rahardjo ${ }^{1}$, Hapsari Dwiningtyas ${ }^{2}$, Lintang Ratri Rahmiaji ${ }^{3}$ \\ \{turnomorahardjo@gmail.com ${ }^{1}$ \} \\ Universitas Diponegoro, Indonesia ${ }^{1,2,3}$
}

\begin{abstract}
This study aims to measure the social distance and social prejudice of Diponegoro University students in terms of friendship and marriage based on gender. This study uses the intertwining conceptual perspective between identity and social distance. The research method used is a survey involving 415 students from various ethnic backgrounds, which are Javanese, Chinese, Sundanese, Batak, Minang, and Papuan. This study found that 415 students have low social distance in terms of friendship and marriage. In terms of friendship, almost all of the students of Javanese, Chinese, Sundanese, Batak, Minang and Papuan ethnicities do not question establishing friendship with individuals from any ethnic background. A relatively similar condition also occurs in terms of marriage. Both of male and female students are "willing" to marry people from different ethnic backgrounds. A fairly large percentage for "refusal" or unwilling to marry people from different ethnicity is seen in Chinese women, Batak women, Minang women, Papuan women, and Papuan men. Although the percentage of unwillingness to marry people from different ethnicity is relatively small, this finding indicates that there is still social prejudice in the form of avoidance and discrimination, which is rejecting individuals from different ethnic groups.
\end{abstract}

Keywords: Ethnicity, Social Distance, Student, Prejudice

\section{Introduction}

Indonesia is the manifestation of a pluralistic society. This plurality is characterized by cultural diversity as seen from differences in customs, ethnicities, regional languages, religions and other cultural values. Pluralism is a view and attitude which emphasizes cultural diversity that can be present in everyday social life. Fay in Lubis [1] emphasized that cultural diversity is not a threat, nor is it a loss or obstacle, but it is more understood as a resource, a mosaic which beautifies life. Each ethnicity, religion or way of life, although different, has an equal position and rights in articulating and expressing their views and values.

Nevertheless, the plurality which manifests in the diversity of cultures is often used to trigger conflicts between groups. The potential for conflict which leads to violence is very likely to occur in a pluralistic society like Indonesia. Why is that? One of the reasons is that society is divided into groups based on their respective cultural identities. People who are divided into groups based on those cultural identity then identify, which is asserting themselves as representations of a particular culture. This cultural identification shall in turn determine them into ingroup or outgroup. How individuals behave is determined in part by whether or not they belong to a particular cultural group. 
In the context of Indonesia's pluralistic society, several cases of disputes between groups based on ethnicity and religion can be found, such as those in Ambon, Poso, Sampit, Cikeusik Banten (Indonesian Ahmadiyya Jamaat case), Mesuji (Lampung), Tolikara (Papua), Aceh Singkil, the acts of persecution committed against Papuans in Surabaya and Malang, and the "eviction" of immigrants in Wamena. All of these incidents show that diversity is very vulnerable or has a great potential for conflict if it is not managed properly. Some of these conflict cases also show that ethnocentric behavior, stereotype, and prejudice are still clearly visible in the relationships between individuals with different cultural backgrounds. In the study of cultural communication, ethnocentric behavior, stereotype, and prejudice are a manifestation of what is called polarized communication, communication which is divided between "our" pole and "their" pole. This occurs when the conflicting parties assume or seriously determine one party's views as true and the other party as wrong. Outside Indonesia, there were cases based on prejudice and ethnocentrism, one of them was the shooting of mosque congregants in Christchurch, New Zealand which killed 51 members of the congregation for Friday prayers in March 2019. The perpetrator, Brenton Harrison Tarrant, an Australian citizen, was suspected of being a white supremacist.

Another case was the act of racism perpetrated by (white) football spectators in Spain and Italy against the athletes or players of black or colored skin. Conceptually, Samovar et al. [2], racism is in many ways an extension of stereotype and prejudice. Racism is a belief about the superiority inherent in certain particular races. Racism shall reject or ignore the principle of human equality. The important thing to note is the word "superiority". It means that a group of people shall mistreat other groups based on race, color, religion, nationality, or sexual preference. Racism occurs when people assume that their race is superior to other people's races. Racist individuals shall often discriminate against people of other races.

Identity is a major issue for most people. It is who we are, who other people are, how we understand ourselves, and how we communicate our identity to others [3]. The interactions between parties with different identities are more or less influenced by the emergence of ethnocentrism, stereotype, and prejudice, because each party tries to understand their identity as "better". The understanding that the identity of one party is "better" than the others is a tangible manifestation of what is called social distance, which is the understanding, attitude, and behavior between two individuals or between individuals and other different groups. The issue of identity can also give rise to social prejudice, which is negative attitude towards a particular group and not based on sufficient evidence. The manifestation of prejudice is anti-locution (talking about people from different groups with negative and stereotypical emphasis), avoidance of interaction, discrimination, physical attack and even extermination (ethnic cleansing). This study aims to measure the social distance and social prejudice of Diponegoro University students from various ethnic backgrounds in terms of interpersonal relationship, which is friendship and marriage based on gender.

\section{Research Method}

This research uses positivism paradigm or in the study of intercultural communication is known as social science paradigm [3]. The social science paradigm assumes that there is an external reality which can be explained, human behavior which can be predicted. The purpose of research is to explain and predict behavior, and culture is a variable which can be measured, as well as culture shall influence communication. At the operational level, the social science 
paradigm is used as a basis for explaining and predicting the behavior of Diponegoro University students from different ethnic groups in establishing interpersonal relationship in terms of friendship and marriage. The method used is a survey.

This study examines the social distancing and prejudice of Diponegoro University students from various ethnic backgrounds (Javanese, Chinese, Sundanese, Batak, Minang, and Papuan) in establishing interpersonal interaction related to friendship and marriage. The population of this research is active students in 2019 at Diponegoro University (UNDIP). The total number of Undip students was 42271 students. The sample size calculation shows that with a population of 42271 , with a confidence level of $95 \%$ and a confidence interval of 5, the number of samples in this study was 381 . The proportion of the sample in this study was made on the basis of the proportion of the number of male and female students and the proportion of the number of students in each. faculty. So that based on sample calculations and proportional considerations based on faculty and gender, the number of samples in this study was 415 respondents.

\section{Results and Discussion}

The sample in this survey research was 415 students of Diponegoro University. The number of female students $(68.2 \%)$ was more than male students $(31.2 \%)$. The majority of students in the sample are Muslim (89.6), the rest are Christian (5.1\%), Catholic (4.6\%), Buddhist $(0.5 \%)$, and Confucian $(0.2 \%)$. Based on their ethnic background, most of the students are Javanese (70.6\%), the rest are Minang (3.9\%), Batak (3.9\%), Sundanese (5.5), and Chinese $(1.7 \%)$ as well as other categories: Papua, Bugis, and Banjar (14.5\%).

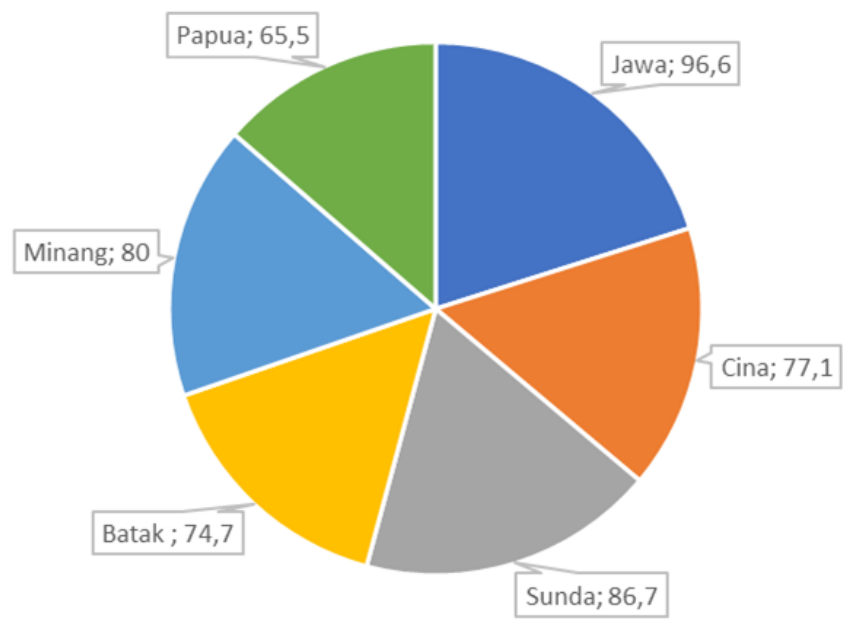

Fig. 1. Ethnic Based Social Distancing.

Based on ethnic backgrounds, in general there is almost no social distance among Diponegoro University students. The lowest social distance is seen from students with Javanese ethnic backgrounds (96.6\%). Meanwhile, students from Chinese, Sundanese, Batak and Minang ethnicities also shows low social distance (in the range of $75 \%$ to $85 \%$ ). Another finding is related to the students' attitude toward other students with Papuan ethnic backgrounds. The 
students can accept the Papuan students (65.5\%), though $34.5 \%$ cannot accept them. This finding seems to indicate that although students of various ethnicities have low social distance, the perception of social distancing towards students from Papua is still relatively high.

In terms of friendship, almost all of the students of Javanese, Chinese, Sundanese, Batak, Minang, and Papuan ethnicities (more than 95\%) do not question establishing interpersonal relationships (friendship) with individuals of any ethnic background. Nevertheless, even though the percentage is relatively small (less than $4 \%$ ), it seems that there are resistances to establishing friendship with other ethnicities, which are towards Chinese men $(3.0 \%)$ and Papuan women $(3.5 \%)$.

Table 1. Resistance to establishing friendship with other ethnicities

\begin{tabular}{|c|c|c|}
\hline $\begin{array}{c}\text { Resistance to } \\
\text { ethnicity }\end{array}$ & Male & Female \\
\cline { 2 - 3 } & $\%$ & $\%$ \\
\hline Java & 1.5 & 0.7 \\
\hline China & 3.0 & 2.8 \\
\hline Sunda & 1.5 & 1.1 \\
\hline Batak & 1.5 & 2.5 \\
\hline Minang & 0.8 & 2.1 \\
\hline Papua & 2.3 & 3.5 \\
\hline
\end{tabular}

A relatively similar condition also occurs in terms of marriage. Both men and women are "willing" to marry people from different ethnic backgrounds. A sizable percentage (in the range of $20 \%-36 \%$ ) for refusal or unwilling to marry people from different ethnicity is seen in Chinese women (24\%), Batak women (26.9\%), Minang women (22.3\%), Papuan women (36.4\%), and Papuan men (28\%). Although the percentage of unwillingness to marry people from different ethnic background is relatively small (less than $40 \%$ ), this finding indicates that there is still prejudice in the form of avoidance and discrimination, which is rejecting individuals from different ethnic groups.

Table 2. Resistance to marrying another ethnicity

\begin{tabular}{|c|c|c|}
\hline $\begin{array}{c}\text { Resistance to } \\
\text { ethnicity }\end{array}$ & Male & Female \\
\cline { 2 - 3 } & $\%$ & $\%$ \\
\hline Java & 3.8 & 2.1 \\
\hline China & 16.7 & 24.0 \\
\hline Sunda & 12.9 & 11.3 \\
\hline Batak & 18.9 & 26.9 \\
\hline Minang & 13.6 & 22.3 \\
\hline Papua & 28.0 & 36.4 \\
\hline
\end{tabular}

Goldon Allport's "Contact" Theory of Prejudice explains that individuals who do not have a close communication with a particular culture shall be more prejudiced against people from that culture [3]. Conceptually, prejudice can be expressed in several ways, either vague or indirect or direct prejudice [2]. The expression of prejudice based on the results of Allport's study is anti-locution, avoidance, discrimination, physical attack, and extermination. Antilocution is talking about a member of the target group in a negative and stereotypical emphasis. The prejudiced people shall avoid interactions with groups they do not like. Another form of prejudice is discrimination. A prejudiced person shall try to deny all members of groups who 
are different in terms of employment, housing, educational opportunities, and places of worship. When discrimination supersedes communication, then open expressions of anger and hatred which hinder other people from enforcing their rights tend to emerge. Physical attack shall be seen, including the destruction or burning of places of worship, and violence against minority groups who are the targets of prejudice. The highest expression of prejudice is extermination. The actions taken led to physical attack against the outgroup. In terms of Indonesia, this expression of extermination emerged in the conflict between ethnic Dayak/Malay and Madurese descent in Sambas and Sampit, and the violence in "May 1998 Tragedy" against Chinese ethnicity or citizens in Jakarta. Prejudice and stereotype shall influence the establishment of effective intercultural communication, because people tend to avoid contact with other people from groups they do not like. If the stereotype and prejudice are so intense, then the prejudiced people shall be involved in an active and discriminatory anti-locution. Such conditions shall lead to confrontation and open conflict.

The findings of this study confirm that social distance in the relationship of Diponegoro University students with different ethnic backgrounds is very low or there is relatively almost no social distance. Likewise, with prejudice. The majority of respondents are willing to establish interpersonal relationships in terms of friendship and marriage. This relatively similar condition is also reflected in the results of the study on Membangun Model Komunikasi Dalam Masyarakat Multiagama [4]. The findings of this study were, in terms of social interaction, citizens in the two research areas (Semarang and Surakarta) can establish good relationship without questioning the origin or background of their respective social, economic, and cultural identities. Thus, people who are high-involved in a particular community, including in a campus environment, they will tend to respect the presence of group diversities in their community. They can also interact politely and try not to offend their communicating partners by maintaining appropriateness in their interactions. However, in terms of personal relationships, some people are still maintaining social distance in particular to people of different ethnicity.

\section{Conclusion}

This study aims to measure the social distance and prejudice of Diponegoro University students in terms of friendship and marriage based on gender. The conclusion conveyed in this study is that in terms of interpersonal relationship (friendship and marriage), the majority of students from various ethnic backgrounds do not question their ethnic origin when establishing friendship, as well as marriage. They are "willing" to marry people from any ethnicity. Conceptually, this condition reflects that they have adequate intercultural communication skills or competencies, in the sense that they are more proactive (mindful) than reactive (mindless) when understanding that there are differences in cultural backgrounds. Intercultural communication competence in its simplest form is an appropriate and effective behavior in a particular context. In more detail, it can be said that intercultural communication competence is the overall capability or internal ability of a person to manage the main challenging aspects of intercultural communication, which are cultural differences and the unknown, intergroup attitudes, and experiences of stress accompanying them [2].

\section{References}

[1] A. Y. Lubis, "Pemikiran Kritis Kontemporer, Dari Teori Kritis, Culture Studies, Feminisme, 
Postkolonial Hingga Multikulturalisme.” Jakarta, PT Raja Grafindo Persada, 2015.

[2] L. A. Samovar, R. E. Porter, E. R. McDaniel, and C. S. Roy, Communication between cultures. Nelson Education, 2017.

[3] J. N. Martin and T. K. Nakayama, Intercultural communication in contexts. McGraw-Hill New York, NY, 2013.

[4] T. Rahardjo and T. Lukmantoro, "Membangun Model Komunikasi Masyarakat Multiagama," Penelit. DIPA Undip, 2015. 